LOCAL WISDOM, 13 (1): 112 - 125, 2021
Local Wisdom Scientific Online Journal
ISSN: 2086-3764

\title{
Significance of Informal Trading Activities in the Emergence of Urban Spatial Vernacular: Case Study of Lagos Island, Nigeria
}

Jolaoso, B. Adekoyejo ${ }^{*}$, Onolaja, O. A.2

1,2,Department of Architecture, School of Environmental Studies Moshood Abiola Polytechnic, Ojere. Abeokuta, Nigeria

Corresponding Author: koyejolaoso@gmail.com

\begin{tabular}{ll}
\hline \multirow{2}{*}{$\begin{array}{l}\text { Keywords: } \\
\text { informal trading; urban } \\
\text { space; built } \\
\text { environment; }\end{array}$} & $\begin{array}{l}\text { Abstract } \\
\text { vernacular; } \\
\text { sustainability }\end{array}$ \\
& Thermal trading activities such as street hawking and sedentary trade \\
& morphology as an urban commercial centre having a vernacular nature \\
& and outlook. This paper seeks to examine the spatial impact of informal \\
& issues in order to evolve a spatial based framework for urban \\
& sustainability. To this end, the paper adopts field survey methodology \\
& with Isale Eko, Lagos Island as the case study area. The theoretical \\
& framework, based on Henri Lefebvre's spatial triad is the underpinning \\
& guide for the field survey. This is supported with Socio-cultural and \\
& Linguistic methods in Anthropology to obtain Primary data, which are \\
descriptively presented. Respondents are nominated using stratified \\
random selection, target groups and participants' observations. \\
Findings reveal that informal trading activities evolve the public space \\
as social space through vernacular and thus, connote socio-cultural \\
expressions in order to ensure livelihood and wellbeing. It further \\
suggests a spatial adaptation strategy to mitigate the challenge of high \\
land use and population density of the island which, from a \\
conventional urban land use perspective, indicates spatial conflict and \\
contestation, hence, a problem. The paper therefore concludes by \\
recommending an inclusive, postmodernism approach which adopts \\
vernacular as a dynamic, sustainable panacea to address urban spatial \\
challenges.
\end{tabular}

\section{INTRODUCTION}

Public space relates to all those parts of the built and natural environment where the public have free access. It encompasses all the streets, squares and other rights of way, whether predominantly in residential, commercial or community/civic uses; the open spaces and parks; and the public/private spaces where public access in unrestricted (at least during daylight hours). Carmona, et al, 2004; 2010) Suffice it is to imply that it includes the interfaces with key internal and private spaces to which the public normally has free access. Public spaces are a common setting in everyday life (Memarovic, et al, 2012). 
Urban public space is the physical space and social relations that determine the use of space within the non-private realms of cities. It is the setting for panoply of human activity and a fundamental determinant of the character of towns (Solomon-Ayeh, et al, 2011). 'True' public space is recognised as being accessible to all groups, providing freedom of action, temporary claim and ownership (Altman \&Zube, 1989; Carr, et al, 1992). Kurniawati, (2012) and Moudon, (1987) describe public space as space for public use. A good public space must accommodative for everyone included the marginal, the forgotten, the silent (Badshah, 1996), and an undesirable people. They are informal street vendors; street people, different ability people, women, children, elderly, and others marginalized community Kurniawati, (2012). Lagos is generally regarded as the financial heart of Nigeria. It is not only the most populous city in the country; it is also the $7^{\text {th }}$ fastest growing city in the world. The city is a metropolis that is considered the crib of cultural life, economic activities, and has white sand beaches. It is also the most diversified place in the country, in terms of people.

Lagos Island is the central business district of the city and is characterised by modern high-rise buildings, roads and businesses. The island also contains many of the city's two most important wholesale market places: the popular Idumota market, the centre of Nigeria's film industry and the Balogun market (Nigeria, 2010). The background information explains the commercial status of Lagos Island and thus, a basis for informal trading activities, as an integral part of the economic activities which impact on the use of public spaces on the island. It is possibly this stead that, Aduwo, et al, (1999), identifies informal trading activities such as Mobile Street trading (hawking), Population concentration induced markets, Sedentary Street trading, and Market induced street trading. While, Akpenyi, (2007) defines street trading, a significant aspect of informal trading activities as any form of buying, selling, hawking or exposing of goods and services in front of residential buildings, offices buildings, railway line setbacks, street corners, beside any road, on pedestrian bridges, on "vehicle" bridges, bus stops and railway terminals, under bill boards, in front of churches or mosques. These are significant public spaces. The understanding of street trading as an informal trading activity in public spaces is applicable to other forms of informal trading activities identified by Aduwo, et al, (1999).Rakobi; et al (2002) describes informal trading activities, as part of strategies which takes place in public space in order to ensure livelihood and wellbeing. Briassoulis, (1999) opines that informal activities are as diverse and extend over the same range as formal, regulated activities, citing, among others, trade and commercial activities (street vending).

\section{AIM}

The aim of the paper is to examine the spatial impact of informal trading activities on the public space with the view to establishing the urban spatial vernacular.

\section{OBJECTIVES:}

- To identify elements or components of informal trading activities on public spaces of the study areas

- To establish the underlying issues surrounding the formation of informal trading activities in public spaces

- To examine their significance in the emergence of an urban spatial vernacular expressions

\section{HYPOTHESES}

- Constraints of Built Environment Morphology $\left(\mathrm{H}_{1}\right)$ : impacts significantly on informal trading distribution patterns, types and land use.

- Ethnic diversity $\left(\mathrm{H}_{2}\right)$ : through informal trading activities, impacts significantly on tribal and ethnic distribution, cultural and religious expression, language use and verbal communication, fashion and dressing culture, product variation, in the public spaces. 


\section{THEORITICAL FRAMEWORK}

The public space significance to informal trading activities is linked to the evolution of social space through man environment interaction, production of space and everyday living as captured as somewhat posited by Lefebvre (1991). Man-Environment interaction connotes man's engagement with physical space. (Lefebvre, 1991; Payne, 1977; Rapoport, 1969; Canter and Stringer, 1975). Space is the result of human engineering to accommodate various forms of life, should be room to stimulate human behaviour and social life (Setiawan, 2004; Kurniawati, 2012).

Space is a means of expression of intent based on activities on the physical environment which fundamentally connotes expressions of everyday life of being, consciousness \& experiences (Lefebvre, 1991). According to Lefevbre (1971), the notion of everyday life was described as the study of everyday life affords a meeting place for specialized sciences and something more besides; it exposes the possibilities of conflict between the rational and irrational in our society and in our time, thus permitting the formulation of concrete problems of production (in its widest sense): how the social existence of human beings is produced, its transition from want to affluence and from appreciation to depreciation. Dalsgaard, et al, (2011) discusses engagement from the perspective of interaction as integral to public space use. Space is the result of human engineering to accommodate various forms of life, should be room to stimulate human behaviour and social life (Setiawan, 2004; Kurniawati, 2012).

Low, (1996), agrees with Lefebvre, (1991) that social space is a whole, and any one event or illustration has within it aspects of that whole. The complex and contradictory nature of space is that "space is permeated with social relations; it is not only supported by social relations but it is also producing and produced by social relations" (Lefebvre 1991:286, as cited in Hayden 1995:31).

Lefebvre (1991) identified space as fundamental to our understanding and interaction with the world, and sought to develop an alternate theory of space that would clarify the role it should play. He posits space as the primary locus of lived experience in the world and has conceived an approach to space, which moves it from the realm of the mental to become the foundation of our engagement with the world. In this his aim was not 'to produce a (or the) discourse on space, but rather to expose the actual production of space by bringing the various kinds of space and the modalities of their generation together' (Lefebvre, 1991: 16, original emphasis). The act of producing space is recognized as fundamental to our experiences of the world, and as such, should be the focus of our attempts at appreciation of that experience.

Informal trading activities have assumed a significant urban commercial phenomenon in Lagos Island and in the context of urban spatial vernacular encapsulates a variety of background issues, understanding, and interpretations (Aduwo et al, 1999; Renooy, 1986; Akpenyi, 2007; Oyesiku, 2010; Nigeria, 2010; Ogunleye \& Alo, 2011; et al). This is perhaps the consequence of the complexities and interplay of socio-economic, political and cultural factors characterising the activities in the public spaces of the study area. The significant aspect of these understanding, its interpretations and implications is the role of the public space as platform for the informal trading activities. 


\section{METHODOLOGY}

\section{STUDY AREA:}
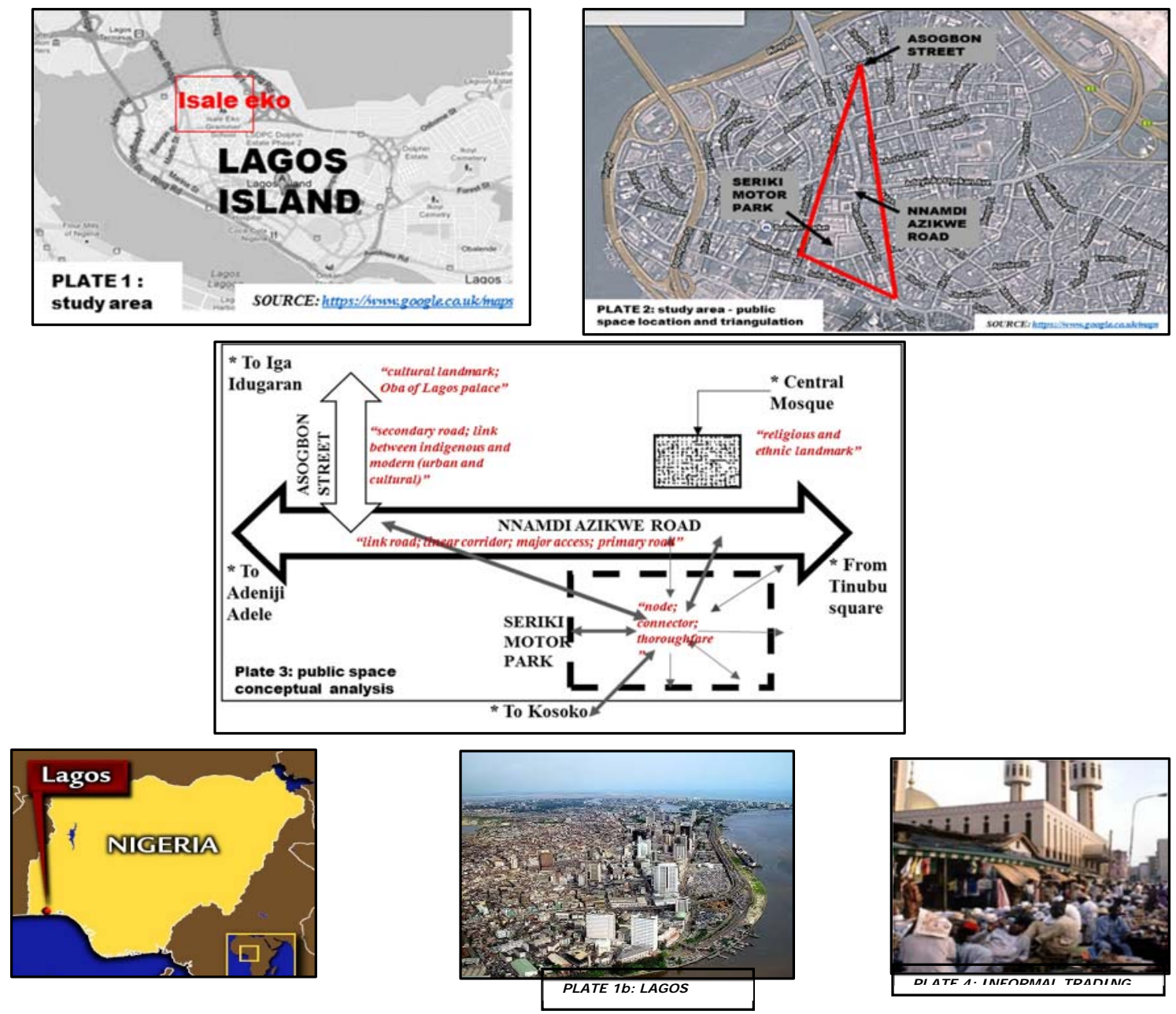

Figure 1. Study area

The paper adopts field survey methodology, theoretical framework, based on Henri Lefebvre's spatial triad is the underpinning guide for the field survey and addresses informal trading activities in terms of street hawking, sedentary trading and open market trading in public spaces with Seriki Motor Park, Nnamdi Azikwe road and Asogbon street in Isale Eko area of Lagos island as case study areas. These were complimented with collected information/data from literature, reviewed, discussed and descriptively presented. The traders involved/respondents were determined through the method of stratified random sampling (at every tenth trader) within the triangulate case study locations. The factors influencing their respective roles were studied and analysed in order to determine how they have impacted on spatial use, definition and interpretations of the public spaces. The study factors considered are Constraints of Built Environment Morphology, Ethnic Diversity, Gender Representation and Climatic considerations. 
Significance of Informal Trading Activities in the Emergence of Urban Spatial Vernacular:

Case Study of Lagos Island, Nigeria

Jolaoso, B. Adekoyejo, Onolaja, O. A.

Table 1: Showing Derivation of Case Studies Sample Size Determination Population Survey

\begin{tabular}{|l|l|l|l|l|}
\hline PUBLIC SPACE & $\begin{array}{l}\text { POPULATION } \\
\text { SAMPLE SIZE }\end{array}$ & $\begin{array}{l}\text { STUDY SAMPLE } \\
\text { SELECTED THROUGH } \\
\text { STRATIFIED RANDOM } \\
\text { SAMPLING METHOD }\end{array}$ & $\%$ & $\begin{array}{l}\text { INFORMAL } \\
\text { TRADING } \\
\text { ACTIVITIES. }\end{array}$ \\
\hline $\begin{array}{l}\text { Nnamdi Azikwe } \\
\text { Road }\end{array}$ & $\begin{array}{l}50 \text { informal } \\
\text { trading } \\
\text { activities/traders }\end{array}$ & $\begin{array}{l}\text { 35 sedentary trading } \\
\text { activities/traders }\end{array}$ & $70 \%$ & $\begin{array}{l}\text { Sedentary } \\
\text { trading }\end{array}$ \\
\hline Seriki Motor Park & $\begin{array}{l}20 \text { informal } \\
\text { trading } \\
\text { activities/traders }\end{array}$ & $\begin{array}{l}18 \text { street hawking } \\
\text { activities/traders }\end{array}$ & $90 \%$ & Street hawking \\
\hline Asogbon Street & $\begin{array}{l}20 \text { informal } \\
\text { trading } \\
\text { activities/traders }\end{array}$ & $\begin{array}{l}16 \text { indigenous open market } \\
\text { trading activities/traders }\end{array}$ & $80 \%$ & $\begin{array}{l}\text { Indigenous open } \\
\text { market trading }\end{array}$ \\
\hline
\end{tabular}

Source: Authors' Field Survey, 2014

Table 2: Breakdown of Study Factors

\begin{tabular}{|l|l|}
\hline \multicolumn{1}{|c|}{ FACTORS } & \multicolumn{1}{c|}{ ISSUES } \\
\hline $\begin{array}{l}\text { Constraints of Built } \\
\text { Environment Morphology }\end{array}$ & $\begin{array}{l}\text { Existing public space characteristics influenced by land use } \\
\text { distribution, patterns and configuration }\end{array}$ \\
\hline Ethnic Diversity & $\begin{array}{l}\text { Tribal and ethnic distribution, cultural and religious expression, } \\
\text { language use and verbal communication, fashion and dressing } \\
\text { culture, product variation. }\end{array}$ \\
\hline Gender Representation & $\begin{array}{l}\text { Male to female ratio, gender in trade preference, gender in trade } \\
\text { specialization. }\end{array}$ \\
\hline Climatic Considerations & $\begin{array}{l}\text { Physical manifestation of indigenous climatic consideration strategies } \\
\text { in built form on public space, materials use and spatial adaptation, } \\
\text { use, definition and interpretations for informal trading activities }\end{array}$ \\
\hline
\end{tabular}

Source: Authors’ Field Survey, 2014

These factors and the corresponding issues evolve the study hypotheses, which are tested in order to to establish the significance of informal trading activities in the emergence of Urban Spatial Vernacular.

In order to investigate these factors and test the hypothesis, the study adopts qualitative methods based on phenomenal methodology approaches background of case study, ethnography (overt and covert participant observation), anthropology and feminist perspectives (Neville, 2007; Moran, 2002; Lester, 1999; et al). The qualitative methods are overt and covert participant observation with the aid of semi structured and unstructured interviews. The findings are descriptively analysed and discussed in order to verify the hypothesis. 


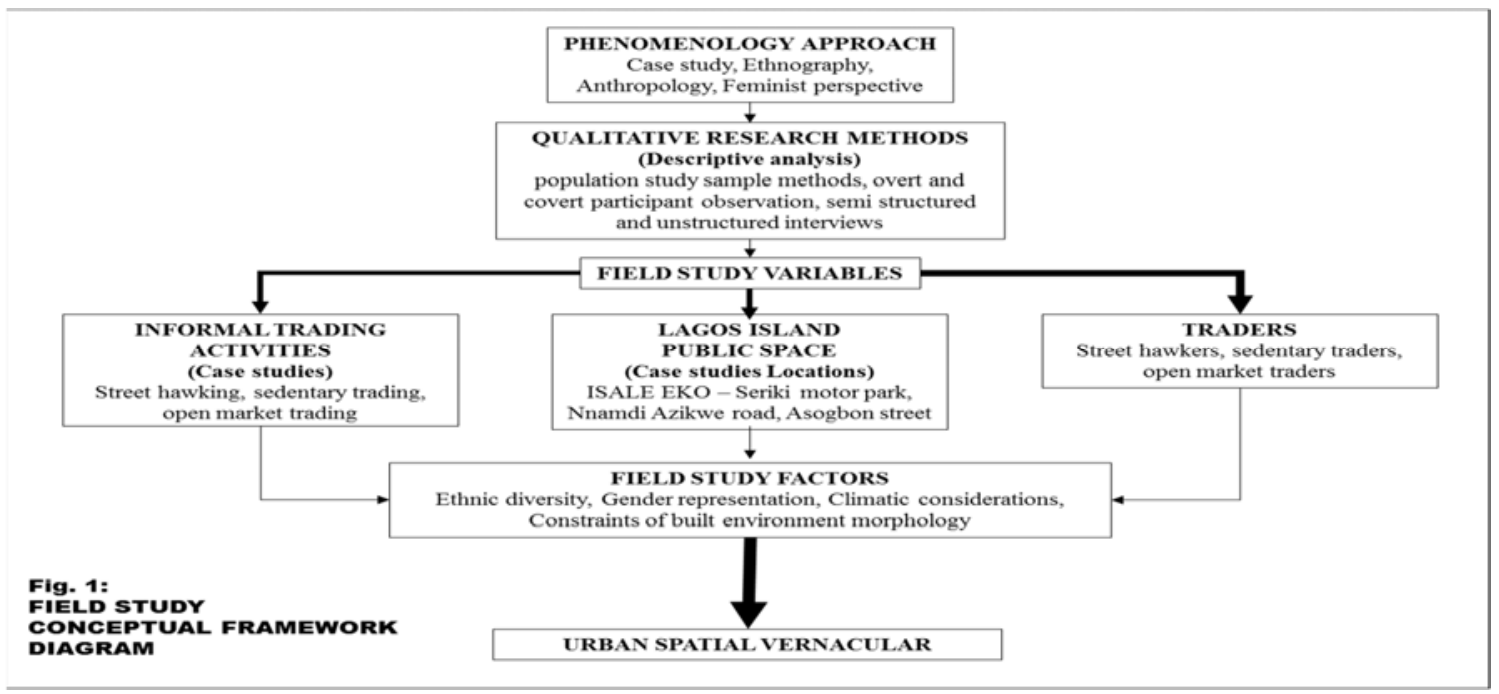

Table 3: Summary of Methodology

\begin{tabular}{|c|c|c|c|}
\hline $\begin{array}{l}\text { Phenomenology } \\
\text { Approach }\end{array}$ & Field Study Factors & Field Study Issues & $\begin{array}{c}\text { Qualitative } \\
\text { Research Methods }\end{array}$ \\
\hline Case Study & $\begin{array}{l}\text { Informal trading } \\
\text { activities }\end{array}$ & $\begin{array}{l}\text { Ethnic diversity, Gender } \\
\text { representation, Climatic } \\
\text { considerations, Constraints of } \\
\text { Built environment morphology. }\end{array}$ & \multirow{3}{*}{$\begin{array}{l}\text { population study, } \\
\text { overt and covert } \\
\text { participant } \\
\text { observation, semi } \\
\text { structured and } \\
\text { unstructured } \\
\text { interviews (Neville, } \\
\text { 2007) }\end{array}$} \\
\hline $\begin{array}{l}\text { Ethnography \& } \\
\text { Anthropology }\end{array}$ & $\begin{array}{l}\text { - Ethnic diversity } \\
\text { - Constraints of Built } \\
\text { environment } \\
\text { morphology } \\
\text { - Climatic } \\
\text { considerations }\end{array}$ & $\begin{array}{l}\text { Tribal and ethnic distribution, } \\
\text { Spatial use and adaptation, etc. }\end{array}$ & \\
\hline $\begin{array}{l}\text { Feminist } \\
\text { Perspective }\end{array}$ & $\begin{array}{l}\text { - Gender } \\
\text { representation }\end{array}$ & $\begin{array}{l}\text { Male to female ratio, gender in } \\
\text { trade preference, gender in trade } \\
\text { specialization. }\end{array}$ & \\
\hline
\end{tabular}

Source: Authors' Field Survey, 2014

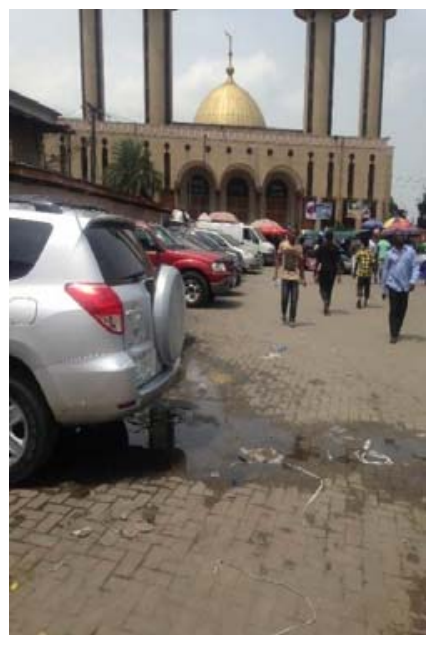

PLATE 5: Seriki Motor Park Source: Authors' field study, 2014

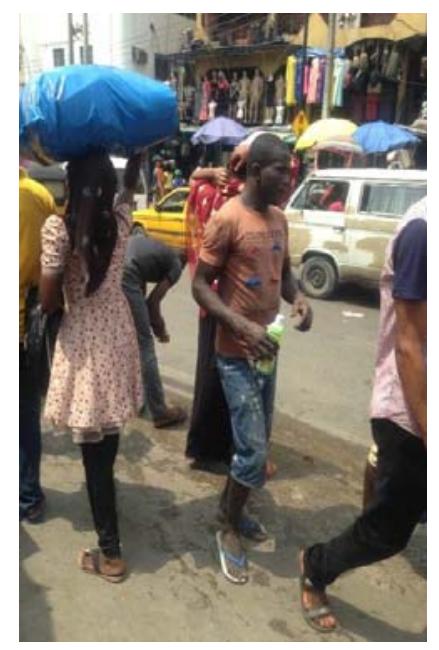

PLATE 6: Nnamdi Azikwe road Source: Authors' field study, 2014

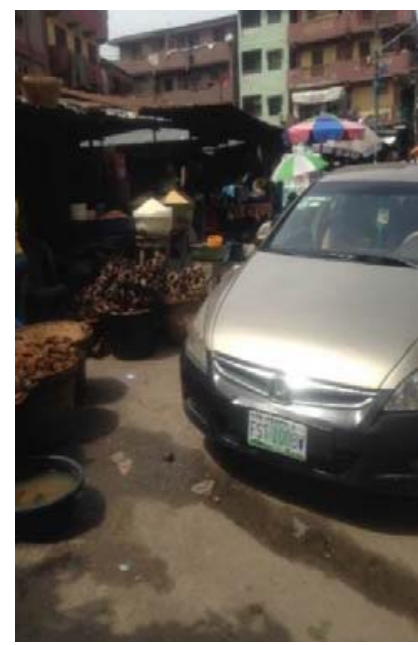

PLATE 7: Asogbon street Source: Authors' field study, 2014 
Significance of Informal Trading Activities in the Emergence of Urban Spatial Vernacular: Case Study of Lagos Island, Nigeria Jolaoso, B. Adekoyejo, Onolaja, O. A.

\section{FINDINGS AND DISCUSSION}

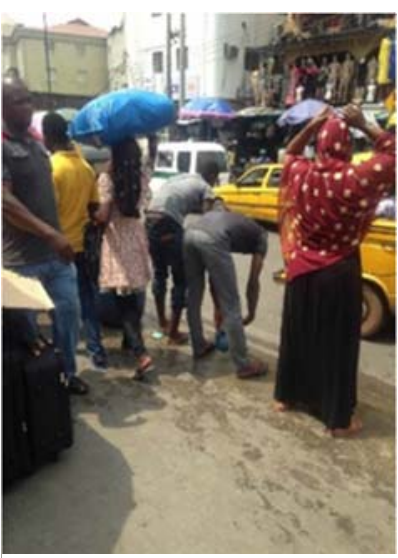

Fig. 8: answering the call for prayer Source: Authors' field study,

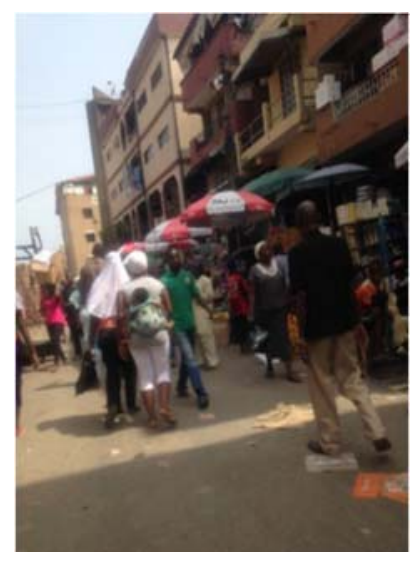

Fig. 9: sedentary trading activities Source: Authors' field study, 2014

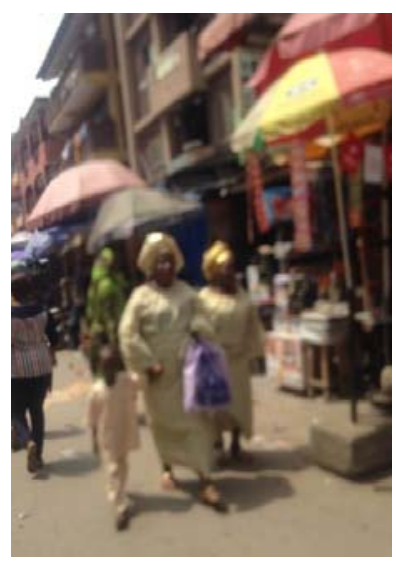

Fig. 10: Yoruba traditional attires Source: Authors' field study, 2014

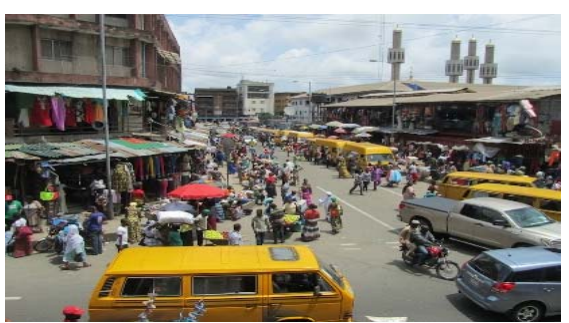

PLATE 11: Built infrastructure around Seriki motor park Source: https://www.google.co.uk/maps

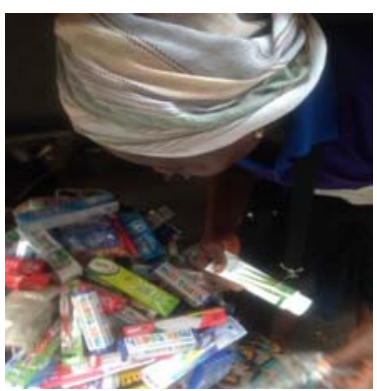

PLATE 12: street hawker displaying her wares

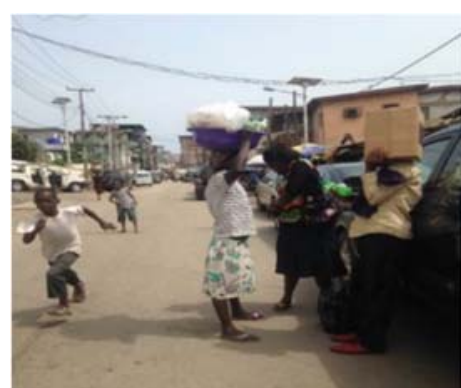

PLATE 13: street hawkers chatting in open space. A reflection of public space as vernacular social space

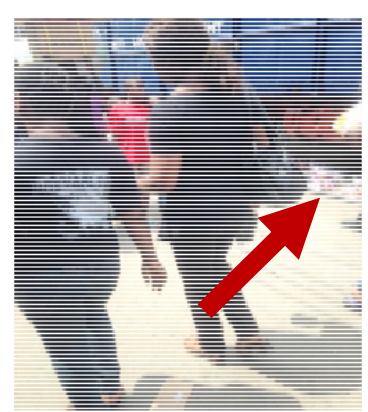

PLATE 14: Adaptability of space street hawkina aoods

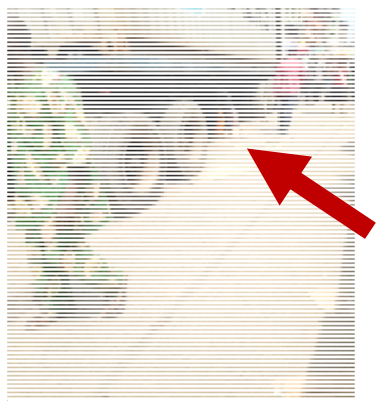

PLATE 15 Adaptability of space for shade and rest

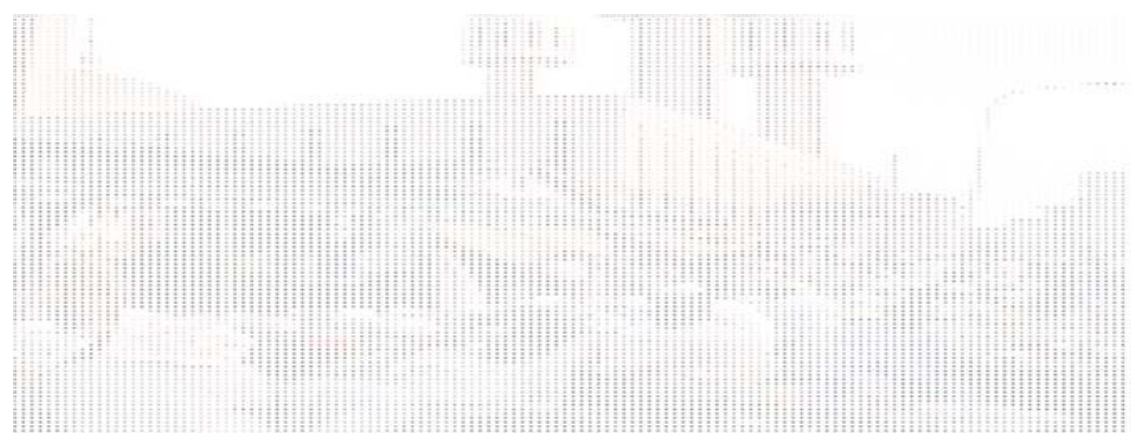

PLATE 16: Hausa men engaged in sedentary trading activities. A social space scenario Source: https://www.google.co.uk/maps 


\section{PUBLIC SPACES ACTIVITIES}

The public spaces are located in Isale-Eko, Lagos island (Plates. $\mathbf{1 ~ - 1 b ) . ~ T h e y ~ a r e : ~ S e r i k i ~}$ Motor Park, Asogbon Street and Nnamdi Azikwe road (Plate. 2).Findings indicate that the use of the public spaces is influenced by land use spatial distribution, urban significance in Isale-Eko, land use patterns and configuration (plate. 3; Table 1). This influences the type and distribution of the respective informal trading activities and how they have adapted to the respective public spaces.

Table 4: Public Space Activities

\begin{tabular}{|c|c|c|}
\hline Public space & Description & Spatial Significance \\
\hline $\begin{array}{l}\text { Nnamdi } \\
\text { Azikwe Road }\end{array}$ & $\begin{array}{l}\text { - Linear corridor of vehicular and pedestrian } \\
\text { traffic route, building setback, designed } \\
\text { with access link ways. } \\
\text { - Comprises of roadway, pedestrian } \\
\text { path/building setback and a major } \\
\text { vehicular and pedestrian link way, hence, } \\
\text { a multifunctional route designed for } \\
\text { vehicular and pedestrian traffic (plate. 6). }\end{array}$ & $\begin{array}{l}\text { A busy route, a major access connecting to } \\
\text { important locations in the study area. } \\
\text { Nnamdi Azikwe road aligns with the central } \\
\text { mosque which is also directly opposite the } \\
\text { Seriki motor park (plate 5), hence a source of } \\
\text { attraction and consequently, human } \\
\text { activities. } \\
\text { The presence of the central mosque along } \\
\text { Nnamdi Azikwe road further impacts on the } \\
\text { definition of the space as temporary prayer } \\
\text { ground for the Muslim traders and non- } \\
\text { traders (plate 8). }\end{array}$ \\
\hline $\begin{array}{l}\text { Seriki motor } \\
\text { park }\end{array}$ & $\begin{array}{l}\text { - Irregular polygonal shaped open paved } \\
\text { space, designed for vehicular parking, } \\
\text { centrally located hence a major nodal } \\
\text { feature in the study area. } \\
\text { - Comprises of paved open space which } \\
\text { serves as a major parking lot on Lagos } \\
\text { Island and pedestrian thoroughfare to } \\
\text { other areas on the Island (plate 5). }\end{array}$ & $\begin{array}{l}\text { A thoroughfare, multiple accesses within and } \\
\text { without, relatively central location to major } \\
\text { buildings, locations and built environment } \\
\text { infrastructure in the study area. } \\
\text { A major distribution point through the use for } \\
\text { motor parking. } \\
\text { A relative central location in the study area. }\end{array}$ \\
\hline $\begin{array}{l}\text { Asogbon } \\
\text { street }\end{array}$ & $\begin{array}{l}\text { - A narrow street with vehicular access } \\
\text { route, pedestrian traffic route, designed } \\
\text { with access link ways. } \\
\text { - Comprises of a minor road with } \\
\text { significance as a link from the major core } \\
\text { (Nnamdi Azikwe road and beyond) to the } \\
\text { inner core (Iga Idugaran - Oba of Lagos } \\
\text { palace, and beyond). Conceptually, this } \\
\text { street links the cosmopolitan urban with } \\
\text { the indigenous cultural, hence, a } \\
\text { significant factor in urban spatial } \\
\text { vernacular (plate. 7). }\end{array}$ & $\begin{array}{l}\text { A major tributary which connects other minor } \\
\text { streets to the major road, Nnamdi Azikwe } \\
\text { road. It also leads to other routes to the } \\
\text { cultural centre of the study area - Iga } \\
\text { Idugaran. }\end{array}$ \\
\hline
\end{tabular}

Source: Authors' field Survey, 2014

Findings indicates that the linear configuration of the roads (especially that of Nnamdi Azikiwe) provides a spatial corridor for row arrangement, suitable for sedentary trading activities (Table 3; Plates 1). This is further enhanced as the road passes through a high density built up area with mixed use buildings which serve as sedentary sales outlet, goods storage facilities, accommodation and offices on both sides of the road (Plates 6, 8, 9, 10; table 4). Findings also show a variety of mixed use buildings accommodating people from diverse ethnic background align the road. The strategic location of the road in the area has a significant contribution to this, and it shows in the fact that out of the 35 traders interviewed, 13 were Hausa; 13 were Ibo; 7 were Yoruba and the remaining 2 were from other parts of Nigeria. 
Table 5 shows the submissions obtained, using unstructured interview from the 35 sedentary traders which indicates the impact of the road configuration on their sedentary trading activities/ patterns. This was in turn used in testing the hypothesis $\left(\mathbf{H}_{\mathbf{1}} \mathbf{)}\right.$.

Table 5: Analysis of Priority Factors

\begin{tabular}{|l|l|l|}
\hline PRIORITY FACTOR & $\begin{array}{l}\text { CONSIDERATION } \\
\text { PERCENTAGE }\end{array}$ & \multicolumn{1}{c|}{ JUSTIFICATION } \\
\hline \begin{tabular}{|l|l|} 
Adaptive reuse of space \\
$\begin{array}{l}\text { Vehicular and } \\
\text { pedestrian movement } \\
\text { pattern }\end{array}$
\end{tabular} & $35 / 35=100 \%$ & $\begin{array}{l}\text { - } \mathbf{3 5}=\mathbf{1 0 0 \%} * * * \\
\text { Congested nature of the space, need to maximize the } \\
\text { available space in order to accommodate as much } \\
\text { goods as possible } \\
\text { Need to attract as many potential customers as possible } \\
\text { due the spatial significance of the road in the study } \\
\text { area. }\end{array}$ \\
\hline $\begin{array}{l}\text { Strategic location of the } \\
\text { road in the study area. }\end{array}$ & $22 / 35=62.86 \%$ & $\begin{array}{l}\text { Anticipated high volume of vehicular and pedestrian } \\
\text { movement along corridor enhances chances of meeting } \\
\text { customers. }\end{array}$ \\
\hline
\end{tabular}

\section{Source: Authors' field survey, 2014}

The traders argued that these three factors are interwoven, but factors 1 and 2 ranks the joint highest priority. They stated further that from observations, customers are attracted to sedentary shops where the physical finesse is comparatively better than the next, even if the products are similar. This confirms the significance of first impression in marketing strategy. All the traders indicated that physical attraction of their shop is a major consideration, hence, an adaptive reuse of space in and around their shop in order to attract customers and beat competition (Plates 6, 8, 9, 10-16). This position gives adaptive reuse of space an edge among the three factors, based on physical finesse. Personal initiative through the use of indigenous approaches is observed in the study. This is peculiar with the Hausa sedentary traders examined.

9 out of the 13 (69.23\%) Hausa traders adopt the "Zaure" concept in designing their stall, a reflection of native beliefs about a building facade. In addition, the concentration of the Hausa traders creates a dominant Hausa "genus loci", a social space interpretation to observers, customers and passers-by in the public space.

Findings also show that the "Zaure" concept at the entry to the shop connotes religious and cultural significance. In Hausa culture hospitality is very important. Islam is at the core of religious obligations. Hence the "Zaure", through the sedentary trading activities, serves multiple purposes of trading, hospitality and religious obligation in the public space (Table 16). While for the Ibo Traders, findings from unstructured interview and passive observations indicated that 12 out of the $13(92.3 \%)$ Ibo traders engage their customers using the "pidgin" English language; indigenous Ibo language is used as secondary language for communication. Cumulative average findings from unstructured interview shows that the 13 Ibo traders believe that everybody living in Lagos, despite the diverse ethnic background can understand the pidgin English language as a vernacular means of verbal communication. It then implies that, using a range of $1-10,9.7$ (97\%) of customers either speak or understand pidgin English. Out of these 97\%, 33\% (3.3) respond in proper English. It then further revealed that most of them understands and are capable of communicating in pidgin English, and such, suggests that there is a significant variation in the role of indigenous language between the two ethnic groups, which in turn emphasises difference in ideology and lifestyle pattern through the trading activities.

The study also revealed that, the open space layout and configuration (especially at Seriki Motor Park) plays a significant role in its use for street hawking, as a consequence of contested and congested high land use density of Isale-Eko of available open space. It 
represents an open platform with overlapping functions of parking, population distribution and street hawking activities for expression, engagement and interaction, which brings about high probability of meeting potential customers. The emergence of informal trading activities was noted to have been encouraged by the nodal road connections bounded by multiple access roads and proximity to major buildings and infrastructure. Out of the 18 street hawkers ( 3 males: 15 females) identified, 2 are Hausa; 3 are Ibo; 13 are Yoruba respectively. The mobile nature street of hawking indicates that the trades encourages social connectivity, engagement, exerts a dynamic and shifting influence on the space and are capable of determining the social characteristics landuse.

The experience from the study of open market trading on Asogbon Street revealed a dense space outlook and organised informal street trading activities, predominantly descendants of the original settlers of Isale Eko (omo onile/Iga Idugaran). It is a somewhat a traditional settlement patterns with market extending from the traditional compound, adapting into an urban area. This area is predominantly populated by traders of the Yoruba ethnic group. It reflects ethnic homogeneity. Traders put on varied attires depicting and preserving their respective native and ethnic identity. Goods and articles are displayed on open shelves and open containers, on mats on the ground and on the bare ground in a cluster arrangement under integrated sheds to facilitate overlapping, interconnected and closely packed indigenous open-market or trading activities in a public space. It therefore suggests that, products sold play a significant role in the configuration of the space.

\section{INFERENCES/DEDUCTIONS}

All these connote social space and suggests how the identified public spaces fit in as an integral part of the urban activities of Isale Eko, Lagos Island and the concomitant role of informal trading activities in the emergence of urban spatial vernacular. Similarly, Table 4 indicates the role of the public spaces as distribution points for pedestrian and vehicular traffic and informal trading activities with interlink and inter-twined overlapping functions and multiplicity socio-cultural, economic, political, religious activities. Thus, a manifestation of contested space expressing a somewhat urban spatial vernacular. These therefore validates the hypothesis

$\left(\mathrm{H}_{1}\right)$ that, the Constraints of built environment morphology impacts significantly on informal trading distribution patterns, types and land use.

$\left(\mathrm{H}_{2}\right)$ : Ethnic diversity through informal trading activities, impacts significantly on population distribution, cultural and religious expression, language use and verbal communication, fashion and dressing culture, product variation, in the public spaces.

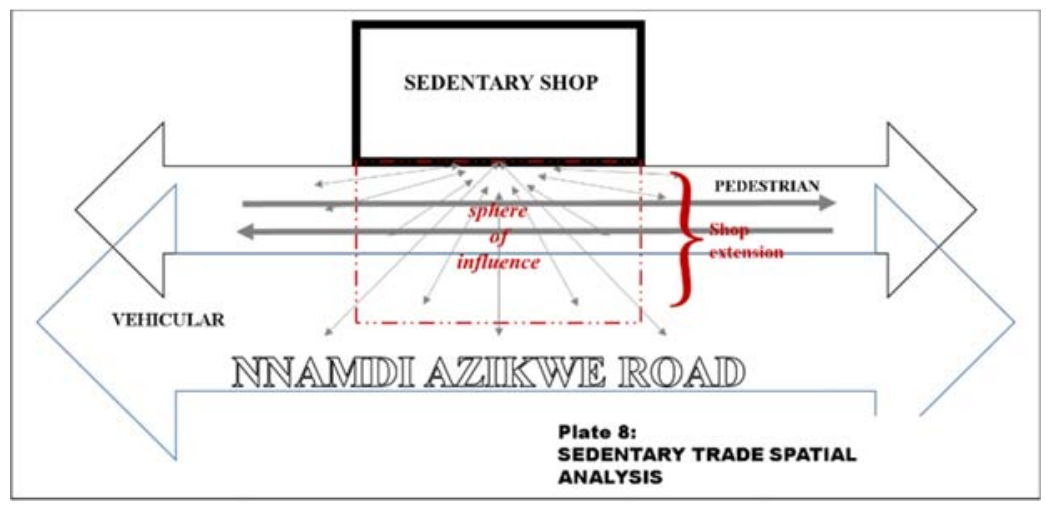




\section{CONCLUSION}

The study shows that the public space, in accommodating various types of informal trading activities is a dynamic tool with multiple possibilities, all evolving into social space. It is a platform for interpreting the dynamics of social interaction and engagement in spatial form. This implies that social space construct is an attribute which defines people behaviour in public space. While, informal trading activities captures the social content of the public space. suffice it is to note that, Informal trading activities in public spaces and the emergence of social space are consequences of people's behaviour and spatial interpretation. Therefore, Informal trading activities in public space is a reflection of everyday living or human interactions with and amongst diverse socio-culture, economic, political etc activities

This study reveals a spatial adaptation strategy to mitigate the challenge of high land use and population density of the island which, from a conventional urban landuse perspective, indicating spatial conflict and contestation, hence, a problem. The paper therefore concludes by recommending an inclusive, postmodernism approach which adopts vernacular as a dynamic, sustainable panacea to addressing the emergence of urban spatial vernacular.

\section{REFERENCES}

Aduwo, A, et al, (1999) in Olaseni A. M. (ed.), (1999). Urban and regional planning in Nigeria: a collection of readings. A publication of the Nigerian institute of Town planners, Lagos State Chapter

Akpenyi, M. E. (2007). Culture and street trading in Lagos metropolis, Journal for sustainable development. 1(2), $78-90$.

Altman, I., and Zube, E., (1989). Public places and spaces, Vol. 10. New York: Plenum Press.

Badshah, A. A., (1996). Our urban future, new paradigms for equity and sustainability, London \& New Jersey: Zed Books Limited.

Bilgiç, Ç. E (2013). The social production of space: occupation, appropriation and boundaries of the dwelling in the case of Ürgüp. Department of urban design and landscape Architecture.

Briassoulis, H. (1999). Sustainable development and the informal sector: An uneasy relationship? The Journal of Environment \& Development, 8(3), 213-237.

Canter, D. and Stringer, P (1975). Environmental interaction. London: Surrey University Press.

Carmona, M. et al (2004). Living places: caring for quality. Office of the deputy prime minister, London.

Carmona, M. (Ed.). (2010). Public places, urban spaces: the dimensions of urban design. Routledge.

Carr, S., et al (1992). Public space. Cambridge: Cambridge University Press. 
Dalsgaard, P., et al (2011). Understanding the dynamics of engaging interaction in public spaces. In Human- Computer Interaction-INTERACT 2011, pp. 212-229. Springer Berlin Heidelberg.

Harvey, D. (1973). Social Justice and the City, Arnold, London.

Hayden, D (1995). The power of place: urban landscapes as people's history. Cambridge: Massachusetts Institute of Technology Press.

Kudva, N. (2009). The everyday and the episodic: the spatial and political impacts of urban informality. Environment and planning. A, 41(7), 1614.

Kurniawati, W. (2012). Public space for marginal people. Procedia-social and behavioural sciences, 36, 476- 484 .

Lefebvre, H. (1971). Everyday Life in Modern World (S. Robinovitch, Translated). Allen Lane, London.

Lefebvre, H. (1991). The Production of Space (N. S. Donald, Translated). Blackwell Publishing, London.

Low, S. M. (1996). Spatializing culture: the social production and social construction of public space in Costa Rica. American ethnologist, 23(4), 861-879.

Memarovic, N., et al (2012). Using public displays to stimulate passive engagement, active engagement, and discovery in public spaces. In Proceedings of the 4th Media Architecture Biennale Conference: Participation, pp. 55-64

Modarres, A. (2006). Urbanization and the revolution: An introduction to the special issue. Cities, 23, 405-406.

Moudon, A V. (1987). Public Street for Public Use. New York: Columbia University Press.

Nigeria, (2010). Nigeria at 50: A compendium. 1st October Publishing. Souvenir edition, 490 499.

Payne G. K. (1977). Urban Housing in the Third World, L. Hill, 1977.

Rakodi, C., \& Lloyd-Jones, T. (Eds.2002). Urban livelihoods: A people-centred approach to reducing poverty. Routledge.

Rapoport A (1969). House Form and Culture. Prentice-Hall, 1969.

Setiawan, Bobi. (2004). Ruang Publik Dan Modal Sosial : PrivatisasiRuang Di Kampung. InfoURDI, Vol. 17, April-Juni.

Solomon-Ayeh, et al (2011). Street vending and the use of urban public space in Kumasi, Ghana. The Ghana Surveyor. (4) 1, 20 - 31.

Stake, R. E. (1995). The art of case study research. Sage. 
Significance of Informal Trading Activities in the Emergence of Urban Spatial Vernacular: Case Study of Lagos Island, Nigeria

Jolaoso, B. Adekoyejo, Onolaja, O. A.

Watkins, C. (2005). Representations of space, spatial practices and spaces of representation: An application of Lefebvre's spatial triad. Culture and Organization, 11(3), 209220.

\section{APPENDIX}

Table 6: Analysis of $\left(\mathrm{H}_{1}\right)$ findings

\section{MAIN JUSTIFICATION}

The high density nature of Isale Eko, hence congestion and lack of space, the Seriki motor park represents an open platform for expression, engagement and interaction, which brings high probability of meeting potential customers.

Furthermore, Street hawking requires open space to thrive and open lifestyle patterns through engagement with space.
IDENTIFIED IMPACT FACTORS

Open space layout and Configuration of Seriki Motor Park

Relative central location in the study area

Mobility nature of street

hawking.

The major distribution point in

Isale Eko for motor parking

and pedestrian take off.

The thoroughfare nature of the park
SAMPLE SIZE

FROM TOTAL (18)

\begin{tabular}{|c|c|c|}
\hline d & 18 & $100 \%$ \\
\hline & 18 & $100 \%$ \\
\hline in & 18 & $100 \%$ \\
\hline & 9 & $50 \%$ \\
\hline
\end{tabular}

- Table 6 shows that the motor park has having overlapping functions of parking, distribution and trading. As a public spatial amenity, this shows a shifting dynamics to the space, with vernacular through street hawking impacting significantly on it. Hence, $\left(\mathrm{H}_{2}\right)$ : Ethnic diversity through informal trading activities, impacts significantly on population distribution, cultural and religious expression, language use and verbal communication, fashion and dressing culture, product variation, in the public spaces.

Table 7: Hausa spatial dynamics table

\begin{tabular}{|l|l|l|}
\hline \multicolumn{1}{|c|}{ Variable } & \multicolumn{1}{|c|}{ Sedentary Shop front use } & Background Vernacular interpretation \\
\hline Customer & Business & Hospitality and trust \\
\hline Visitor & Entertainment & Hospitality and Friendship \\
\hline God & Prayer & Religion, submission and devotion \\
\hline
\end{tabular}

Source: Authors' field survey, 2014

Table 8: Variable Breakdown

\begin{tabular}{|c|c|}
\hline Variable 1 & Reasons for Shop Extension \\
\hline Climatic considerations & $\begin{array}{l}\text { "a" comfort, shade, relaxation and ventilation } \\
\text { "b" more space to display goods in front of shop }\end{array}$ \\
\hline Variable 2 & Types of shop extension \\
\hline Shop extension structure & $\begin{array}{ll}\text { "c" } & \text { Collapsible umbrellas - contemporary } \\
\text { "d" } & \text { Wooden shop extension - mixed conservative } \\
\text { "e" } & \text { Locally crafted tent extension - core indigenous }\end{array}$ \\
\hline
\end{tabular}

Source: Authors' field survey, 2014

\section{Variable (1) findings:}

- "a" impacts significantly on the hypothesis.

- " $\mathbf{b}$ " does not impact significantly on the hypothesis, but indirectly impacts on

"a". 
Table 9: Variable (1) analysis

\begin{tabular}{|c|c|c|c|c|c|}
\hline \multirow[b]{2}{*}{ Ethnic group } & \multirow{2}{*}{$\begin{array}{l}\text { Total number } \\
\text { sampled }\end{array}$} & \multirow[b]{2}{*}{ Reasons } & \multicolumn{2}{|c|}{ Dual choice Ranking } & \multirow{2}{*}{$\begin{array}{l}\text { Importance } \\
\text { Ranking } \%\end{array}$} \\
\hline & & & Important & $\begin{array}{l}\text { Not } \\
\text { important }\end{array}$ & \\
\hline \multirow{2}{*}{$\begin{array}{l}\text { Hausa } \\
\text { traders }\end{array}$} & \multirow{2}{*}{13} & "a" & 13 & & \multirow[t]{2}{*}{$100 \%$} \\
\hline & & “b" & 13 & & \\
\hline \multirow{2}{*}{ Ibo traders } & \multirow{2}{*}{13} & "a" & 6 & 7 & $46.15 \%$ \\
\hline & & "b" & 13 & & $100 \%$ \\
\hline \multirow{2}{*}{$\begin{array}{l}\text { Yoruba } \\
\text { traders }\end{array}$} & \multirow{2}{*}{7} & “a” & 6 & 1 & $85.71 \%$ \\
\hline & & "b" & 7 & & $100 \%$ \\
\hline \multirow{2}{*}{ others } & \multirow{2}{*}{2} & “a" & 1 & 1 & $50 \%$ \\
\hline & & "b" & 1 & 1 & $50 \%$ \\
\hline
\end{tabular}

Variable (2) findings:

- "c" impacts significantly on the hypothesis from a contemporary perspective contemporary vernacular.

- " $\mathrm{d}$ " impacts significantly on the hypothesis from a mixed conservative standard conservative vernacular.

- "e" impacts most significantly on the hypothesis from a core indigenous perspective indigenous vernacular.

In the context of this study, "e" is adopted as benchmark for measuring vernacular.

Table 10: Variable (2) analysis

\begin{tabular}{|c|c|c|c|c|c|c|}
\hline \multirow{2}{*}{ Ethnic group } & \multirow{2}{*}{$\begin{array}{l}\text { Total number } \\
\text { sampled }\end{array}$} & \multirow{2}{*}{$\begin{array}{c}\text { Choice } \\
\text { size }\end{array}$} & \multicolumn{3}{|c|}{ choice combinations } & \multirow{2}{*}{$\begin{array}{l}\text { Sample } \\
\text { score } \%\end{array}$} \\
\hline & & & "c" & "d" & "e" & \\
\hline \multirow{4}{*}{ Hausa traders } & \multirow{4}{*}{13} & 4 & & $x$ & & $30.77 \%$ \\
\hline & & 5 & $\mathbf{x}$ & & $\mathrm{x}$ & $38.46 \%$ \\
\hline & & 3 & & & $x$ & $23.08 \%$ \\
\hline & & 1 & $x$ & $x$ & & $7.69 \%$ \\
\hline \multirow{3}{*}{ Ibo traders } & \multirow{3}{*}{13} & 1 & $\mathrm{x}$ & & & $7.7 \%$ \\
\hline & & 8 & $x$ & $\mathrm{x}$ & & $61.53 \%$ \\
\hline & & 4 & & $x$ & & $30.77 \%$ \\
\hline \multirow{2}{*}{$\begin{array}{l}\text { Yoruba } \\
\text { traders }\end{array}$} & \multirow{2}{*}{7} & 6 & $x$ & $x$ & & $85.71 \%$ \\
\hline & & 1 & & $x$ & & $14.29 \%$ \\
\hline \multirow{2}{*}{ Others } & \multirow{2}{*}{2} & 1 & $x$ & $x$ & & $100 \%$ \\
\hline & & 1 & $x$ & & & $50 \%$ \\
\hline
\end{tabular}

Table 10 reflects a variety of interpretations based on ideological differences which therefore links this hypothesis $\left(\boldsymbol{H}_{4}\right)$ to $\left(\boldsymbol{H}_{2}\right)$. The findings on the Hausa traders who represent the most varied classification are a reflection of this. The variety shows a flexibility of choice in use of materials. It also shows the significance of adaptation of space for multi-use purposes. Therefore, climatic considerations and the use of indigenous building strategies connote subjectivity, through flexibility, adaptive use which is significant factors to urban spatial vernacular. 